\title{
DRAŻLIWOŚĆ I KRYTYCYZM. O ROLI FILOZOFICZNEJ KRYTYKI W KULTURZE I EDUKACJ
}

\begin{abstract}
Streszczenie. W artykule omawiam normatywne aspekty drażliwości - nieadekwatnie silnej reakcji na różnice poglądów i postaw - towarzyszącej współczesnej polaryzacji dyskursu w kulturze Zachodu. Tak jak polaryzacja, drażliwość jest częściowo wytworem medialnym, lecz odzwierciedla również strukturalne problemy kultur i praktyk społecznych opartych na gęstej sieci wartości. Omawiam diagnozy zjawiska i proponowane w filozofii remedia, takie jak odejście od dyskursu opartego na wartościach oraz osłabienie założeń związanych z silnym podmiotem działań i przekonań. Polemizując z tym dwoma rozwiązaniami, proponuję program radykalnego filozoficznego krytycyzmu. Omawiam jego założenia na tle współczesnych teorii krytycznych (między innymi Horkheimera, Spaemanna, Habermasa) oraz pokazuję jego konkretne zastosowanie w praktyce edukacyjnej.
\end{abstract}

Słowa kluczowe: krytycyzm, wartości, nowoczesny podmiot, ironia, drażliwość, edukacja

1. Drażliwość i dyskurs wartości. 2. Wizja słabego podmiotu. 3. Radykalny krytycyzm. 4. Krytycyzm w szkole.

W społeczeństwach, które respektują prawa jednostek i mniejszości, istnieje wprawdzie wolność słowa, lecz niekoniecznie powiększa się akceptacja dla różnorodności opinii. W miejsce cenzury i innych form kontroli dyskursu pojawia się drażliwość. Chroniona przez prawo tolerancja nie powstrzymuje rozdrażnienia i niechęci. Problem ma charakter polityczny i prawny, ponieważ poszczególne podmioty jednostki i grupy - coraz silniej domagają się obecności ich wartości i przekonań w przestrzeni publicznej, natrafiając na rozproszony, lecz niemniej silny opór. Dotyczy to również szkoły. Musi ona zmierzyć się ze zderzeniem tradycyjnej misji szkoły jako międzypokoleniowego transferu wiedzy i kultury z lawinowym wręcz mnożeniem się tematów drażliwych, związanych z różnicami światopoglądowymi i obyczajowymi, kiedy już sama sytuacja dyskusji budzi rozdrażnienie 
jej uczestników. Obecnie nie tylko religia, etyka czy edukacja seksualna zawierają takie tematy, lecz również historia i biologia, a lista będzie się prawdopodobnie wciąż powiększać.

Treści drażliwe mają to do siebie, że uniemożliwiają komunikację, ponieważ już sam fakt komunikowania własnych przekonań czy wartości budzi negatywne uczucia innych, od irytacji i urazy do czynnie manifestowanej odrazy czy wrogości. W tych rozważaniach ustosunkuję się do niedawnej diagnozy problemu przedstawionej przez Eberharda Strauba ${ }^{1}$, twierdzącego, że za trudności współczesnej komunikacji społecznej odpowiada dyskurs wartości, który niefortunnie zastąpił dawniejsze odwoływanie się do godności. Wartości są, według Strauba, czymś, co się nie tylko ceni, lecz także posiada, podziela, broni, podważa, narusza itd. $Z$ pozoru podobnie rzecz się ma z godnością, lecz, zdaniem Strauba, godność posiada się w sposób naturalny, jak własne ciało - ostateczne ugruntowanie godności prowadzi do samej osoby, jej cech i jej działania. Tymczasem w naszym stosunku do wartości jest coś zewnętrznego - obejmuje się je $\mathrm{w}$ posiadanie aktem podobnym do zawłaszczenia albo przez ustanowienie pewnego roszczenia. Konflikty jakie tu powstają przypominają inne konflikty wywołane przez stosunki własności. Analogicznie, jak w domenie własności, trudno jest odwoływać się do własnych wartości i nie naruszając przy tym wartości innych ludzi. Tym samym nie da się uniknąć lęku, braku zaufania i drażliwości cechujących współczesną komunikację społeczną.

Innym sposobem zmniejszania drażliwości jest osłabienie siły przekonań i budowanie tożsamości podmiotów bez odwoływania się do silnych przekonań i postaw aksjologicznych. Postulat ten prowadzi zarazem do ograniczenia racjonalnych założeń dyskursu. Jest to jednak, pod względem normatywnym, rozwiązanie zbyt kosztowne. Bez pojęcia silnego podmiotu bardzo trudno jest obronić

1 E. Straub, Von Tyrraney der Werte, Klett-Cotta, Stuttgart 2010. 
pojęcie odpowiedzialności, a tym samym uzasadnić obowiązywanie jakichkolwiek norm.

W dalszej części artykułu odniosę się krytycznie do obu wymienionych powyżej propozycji. Chcę bronić innego rozwiązania, którego sednem nie jest osłabienie podmiotowości i racjonalności, lecz wręcz przeciwnie, ich pogłębienie i wzmocnienie. Radykalna postawa krytyczna wydaje się na krótką metę zwiększać drażliwość, lecz w dłuższej perspektywie osłabia ją i poprawia jakość komunikacji. Swoją tezę postaram się uzasadnić filozoficznie, a także poprzeć doświadczeniem związanym z prowadzeniem zajęć filozoficznych w szkole, na wczesnym etapie edukacji. Jeśli nie uda się zaradzić drażliwości związanej z tematyką światopoglądową i aksjologiczną, trzeba będzie ponieść konsekwencje w postaci znikania z edukacji, a może w ogóle ze sfery publicznej, ważnych dla człowieka treści. Byłoby to nie tylko stratą dla kształcenia i kultury, lecz także prowadziłoby do zjawisk groźnych społecznie - do tworzenia się zastępczych pól konfliktu i agresji.

\section{DRAŻLIWOŚĆ I DYSKURS WARTOŚCI}

Kiedy przed laty Deborah Tannen publikowała swoją poczytną książkę Cywilizacja któtni ${ }^{2}$ martwiło ją podsycane przez media antagonizowanie dyskursu publicznego - dramatyzowanie, maksymalizowanie różnic, polaryzacja. Organizowanie dyskusji publicznych w jaskrawych opozycyjnych parach stało się, zdaniem tej autorki stałym obyczajem medialnym, naśladowanym coraz częściej w codziennych obyczajach. Wszystko to wywiera, jej zdaniem, destrukcyjny wpływ na jakość dialogu i postrzeganie rzeczywistości. Realna struktura świata nie wspiera $\mathrm{w}$ najmniejszym stopniu spolaryzowanego dyskursu. Ten ostatni jest częścią społecznej gry o władzę i wpływ. W tej grze korzysta się z logiki pozornie i opacznie - zasady logiczne

2 D. Tannen, Cywilizacja kłótni. Jak powstrzymać amerykańską wojnę na słowa, tłum. z ang. P. Budkiewicz, Poznań 2003. 
powołane do tego, by porządkować własne przekonania za pomocą prawidłowych rozumowań stają się tu narzędziem do mechanicznej produkcji i niemniej mechanicznego przypisywania przekonań. Postępuje się tak, jakby do powstawania przekonań wystarczyły inne przekonania (w roli argumentów lub kontrargumentów) i zasady logiki. Tymczasem przekonania nie powstają w ten sposób. Ich podłożem jest wielopoziomowa struktura poznawcza i emocjonalna, która z konieczności zaangażowana jest w każdą poważną dyskusję. Upodobanie do debat spłaszcza te poziomy i przynależne do nich style komunikowania się. Praktyki te są z jednej strony symptomem kryzysu mowy, doświadczenia i komunikacji, z drugiej strony same ten kryzys pogłębiają.

Polaryzacja rodzi agresję, co oczywiście rzuca się w oczy. Rzadziej dostrzega się inne schorzenie dyskursu: narastającą drażliwość. Ponieważ subtelna, bogata treściowo baza naszych przekonań jest coraz bardziej zaciemniona przez polaryzujące praktyki, nie wiemy jak głęboko sięgają różnice pomiędzy nami i innymi ludźmi. Kiedy ta niewiedza sprzęga się $\mathrm{z}$ niskim poziomem zaufania, wytwarza podejrzenie, że różnice sięgają bardzo głęboko, aż do zupełnej niemożliwości rozmowy czy współpracy. Jest to podejrzenie a priori nie da się go empirycznie uzasadnić ani odrzucić. Podejrzliwość, a w ślad za nią drażliwość, nie powstają na podstawie faktów, lecz pomimo faktów. Drażliwość pojawia się już u samych początków komunikacji i wywołuje lawinowe skutki: (1) różnice pomiędzy jej uczestnikami automatycznie ulegają maksymalizacji; (2) poglądy zostają utożsamione z dyspozycją do pewnego działania, a nawet wysokim prawdopodobieństwem tego działania, dlatego nieakceptowane poglądy zaczynają budzić lęk; (3) różnice logiczne nabierają rysów egzystencjalnych; (4) w dyskusjach pojawiają się argumenty „z równi pochyłej”; (5) wątpi się w końcu w niewinność samej mowy, ponieważ znika różnica pomiędzy mową i działaniem - mowa traktowana jest jak czyn, za którym nie stoi interes samej mowy (komunikacja, ekspresja, prawda), lecz zawsze interes mówiącego. 
Oczywiście wiemy, że wymienione wyżej zależności mają często miejsce. Na przykład współczesne analizy czynności mowy, pokazując zawarte w wypowiedziach implikatury, pouczają nas o bogatej strukturze działania ukrytej w mowie. Jednak działanie drażliwości polega na pojawieniu się wszystkich tych zależności w niepodatnym na refleksję splątaniu. Redukowanie mowy do działania i interesu mówiącego nie jest tu konstatacją naukową, opartą na empirycznych czy analitycznych świadectwach, lecz pewną postawą - kulturą podejrzenia i obwinienia.

We wspomnianej książce, której styl i przesłanie leżą w pół drogi pomiędzy analizą filozoficzną i zaangażowaną publicystyką, Eberhard Straub twierdzi, że za tę głęboką patologię komunikacji odpowiada dyskurs wartości, który w czasach nowożytnych zastąpił stopniowo dawniejsze odwoływanie się do godności. Zdaniem Strauba nie sposób odwoływać się do własnych wartości i zarazem nie naruszyć wartości innych ludzi, podczas gdy taka zależność nie zachodzi w przypadku godności. Tym samym na gruncie dyskursu wartości, nie da się uniknąć lęku, braku zaufania i drażliwości cechujących współczesną komunikację społeczną. Chociaż Straub nie pisze osobno o drażliwości, to jednak jego krytyka stosuje się do dyskutowanego tu tematu. Otóż wypowiedzi wywołują reakcję drażliwości już przez samo to, że wyrażają wartości uznawane przez mówiącego. Uznanie wartości implikuje możliwość oceniania, tak jak posiadanie broni implikuje możliwość jej użycia. Tak też traktują wypowiedzi rozmówcy nastawieni na wartości. Trudno jest wskazać akceptowaną przez siebie wartość, nie wskazując jednocześnie na wartość, której się nie akceptuje. Za tą ostatnią stoją jednak zawsze jacyś zwolennicy. Zachodzi tu znów analogia $\mathrm{z}$ własnością: $\mathrm{w}$ wysoce zorganizowanej cywilizacji trudno jest napotkać przedmiot czy fragment przestrzeni, który byłby niczyj - niemal każdemu da się przypisać pewną linię prowadzącą do własności czy pewnego roszczenia - dlatego najmniejsza nawet ingerencja w materialne stany rzeczy łatwo prowadzi do sporu, w tym również sporu prawnego. 
Inna negatywna konsekwencja płynie z samej gęstości pola wartości. Wartość wyznacza klasę przedmiotów pod te wartość podpadających. Nie może istnieć przedmiot, który z definicji jako jedyny miałby pewną wartość. Może się na przykład zdarzyć, że pozostanie tylko jeden człowiek uczciwy na świecie, lecz to nie znaczy, że klasa ludzi uczciwych jest jednoosobowa - zawiera bowiem również przyszłych i możliwych ludzi uczciwych. Przedmioty należące do klasy wyznaczonej przez wartość, mają też własności zaliczające je do innych klas aksjologicznych. Jeśli struktura aksjologiczna jest bogata, to rośnie prawdopodobieństwo powstawania sprzeczności aksjologicznych - przedmiot jest oceniany pozytywnie w jednym systemie odniesienia i negatywnie w innym, przy czym systemy te nie wykluczają się wzajemnie - zachowują równe roszczenie do ważności.

Jeśli uznaję jakąś wartość, czynię to zawsze z pewnym roszczeniem dotyczącym innych ludzi: zakładam, że jest ona wartością również dla innych. Lecz inna osoba, nieafirmująca tej wartości, zgłasza automatycznie przeciwstawne roszczenie, to mianowicie, że nie powinienem uznawać tej wartości, którą uznaję. Różnica staje się więc antagonizmem. Jedynym rozwiązaniem byłoby uznanie, że każdy ma swoje własne wartości, lecz wówczas unieważniałoby się powody do ich uznawania, bronienia, argumentowania na ich rzecz. Do życia w społeczeństwie potrzebujemy wspólnoty wartości, a z drugiej strony potrzebujemy relatywizacji pozwalającej na rozbieżność osobistych wartości. Nie wydaje się, by istniała racjonalna procedura utrzymująca tego rodzaju równowagę. Wymagałaby bowiem pewnej ograniczającej hermeneutyki, która wydaje się trudna do osiągnięcia, o czym świadczą dzieje zasady tolerancji: po wiekach dyskusji wciąż nie ma jasności co do tego, jakie konkretne działania czy postawa są najlepszym realizatorem tej zasady: cierpliwość, ignorowanie, uznanie, poszanowanie, akceptacja, afirmacja? Tolerancja staje się stopniowo zasadą pełną sprzeczności i pomimo szlachetnego rodowodu nie pomaga nam dziś bardzo w ustalaniu wspomnianej wyżej równowagi. 
Wartości wywierają niepodlegający racjonalnej kontroli wpływ na preferencje. $Z$ pozoru zależność jest bardzo prosta: wolę $A$ od $B$, ponieważ wartość A leży wyżej w mojej hierarchii wartości (bardziej cenię A niż B). Jednak liczne badania eksperymentalne pokazują, że nasze systemy preferencji są bardzo czułe na zaburzenia. Często zmieniamy nasze preferencje przed działaniem i to pod wpływem mało istotnych bodźców. W jednym z eksperymentów ${ }^{3}$ badani mieli zdecydować, za jaką zapłatę zgodziliby się słuchać przez jakiś czas bardzo nieprzyjemnego dźwięku przygotowanego przez eksperymentatora. Najpierw jednak przygotowana została przykładowa wycena 300 sekund słuchania tego dźwięku. Dokonano tego w sposób całkowicie arbitralny, dla każdej osoby badanej ustalono taką cenę oddzielnie za pomocą numeru jej dokumentu tożsamości. Arbitralność ta była znana osobom badanym, teoretycznie więc mogły one tę pseudowycenę zignorować. Następnie każda z osób miała powiedzieć za ile sama zgodziłaby się rzeczywiście wysłuchać tego dźwięku przez przykładowy czas. Okazuje się, że osoby badane o niższych liczbach wygenerowanych $z$ ich numerów dokumentów decydowały się słuchać tej samej porcji dźwięku za mniejszą zapłatę. Eksperyment ten pokazuje zjawisko, które można też zaobserwować w codziennym życiu: wystarczy, że pojawia się, choćby tylko hipotetycznie (bez silnych powodów do afirmacji), nowa wartość, by zmienić siłę obstawania przy innych wartościach.

Podsumowując: Język wartości pojawił się, zdaniem Strauba, wraz z kapitalizmem. Bycie kimś (związane z godnością) zostało zastąpione posiadaniem czegoś wartościowego. Kiedy przekonania wyrażone są w języku wartości, powstają nieuchronnie konflikty. Tej wady nie ma, zdaniem Strauba, język godnościowy. Godność jest równo podzielona pomiędzy osoby. Osobista godność nie jest przedmiotem uniwersalizacji i nie można jej zaspokoić cudzym kosztem,

3 D. Ariely, G. Loewenstein, D. Prelec, Tom Sewyer and the Construction of Value, w: The Construction of Preference, red. P. Slovic, S. Liechtenstein, Cambridge 2006, 261. 
a zatem nie powoduje konfliktu. Zamiast prowadzić do debat na temat wyższości jednych wartości nad innymi, dyskurs godnościowy rodzi wezwanie do samodoskonalenia.

Zgadzając się ze Staubem co do negatywnych cech dyskursu aksjologicznego, nie sądzę, by alternatywa godnościowa stanowiła remedium. Po pierwsze jest irracjonalna. Godność jest tak heterogeniczna, że nie można na nią liczyć jako na predykatora zachowań. Inaczej mówiąc, jeśli chodzi o wytwarzanie preferencji, godność jest jeszcze mniej wiarygodna niż wartości. Nie wiadomo, co w danej sytuacji wybierze osoba kierująca się poczuciem godności. Po drugie, godność wymaga uzasadnienia, a wtedy pojawia się na powrót odwołanie się do wartości.

\section{WIZJA SŁABEGO PODMIOTU}

Inną strategią zmniejszenia drażliwości jest osłabienie pojęcia podmiotu. Nie chodzi już o to, co jest powodem rozdrażnienia i braku zaufania, lecz o to, kto tych uczuć doznaje. Przy słabym pojmowaniu samego siebie (jako „niezupełnego” posiadacza przekonań, wykonawcy działań itd.) nie dochodzi do zderzania się podmiotowych roszczeń. Zderzenia te są wyrazem impasu, braku ruchu w grze społecznej - chodzi więc o to, by uczestnicy dyskursu zawsze taki ruch posiadali. Sposobem realizacji tej strategii jest swoiście pojmowana postawa sceptyczna. Została ona wnikliwie opisana w ostatniej książce Szymona Wróbla Lektury retroaktywne. Autor wychodzi od filozoficznej krytyki postaw zorientowanych na tożsamość podmiotu i uniwersalne zasady. Podsumowuje te krytyczne wyniki następująco: „Myślę, że wolność podmiotu myślącego, tj. sceptyka zawieszającego, to nade wszystko wolność wynikająca z uwolnienia się od obsesji ostatecznego uprawomocnienia. Misje takiego uprawomocnienia wzięła na siebie filozofia, a potem socjologia z obawy przed sceptycyzmem, który uważała za intelektualnie i moralnie nieakceptowany. Dla sceptyka myśleć oznacza posługiwać się zasobami pojęć samej 
filozofii, psychoanalizy, sztuki oraz myślenia potocznego, ze swobodą wyzwoloną przez rozpoznanie rozmaitych znanych już sposobów myślenia. Myśleć oznacza unikać ślepych zaułków dyskursów 'domkniętych' na własne pojęcia, czyli dogmatycznych i uwodzących absolutyzmem swych konstrukcyjnych roszczeń. Dla sceptyka filozofia i historia, psychoanaliza i sztuka nie dążą do wiedzy, są wyłącznie praktykowaniem inteligentnego, myślącego życia, a więc czynnością życia samego, nie zaś jej transcendentnym produktem”4.

Na postawę opisaną przez Autora składają się: sceptycyzm rozumiany jako niechęć do dogmatyzmu, rezygnacja z silnych warunków tożsamości, z którymi związane było tradycyjne pojęcie podmiotu, swoboda używania rozumu, czyli zdolność do zmieniania zasad i aparatury pojęciowej, wrażliwość na kontekst, rezygnacja z pewnej części tradycyjnego dyskursu normatywnego na rzecz dyskursu psychoanalitycznego, ironia i dyskursywne przemieszczenie pozwalające unikać ślepych uliczek poznania i komunikacji i czyniące zadość świadomości własnych ograniczeń, wreszcie empatia będąca lepszym niż zasady przewodnikiem w rozwiązywaniu problemów. Jest to program radykalny i bogaty. Szymon Wróbel stawia niejako kropkę nad ,i”, formułując wyraźnie i praktycznie konsekwencje płynące z ponad stuletniej odysei krytycznego rozumu. Jednak niektóre składniki jego diagnozy i recepty budzą wątpliwości:

1. Wysiłki sceptyka mogą być wprawdzie motywowane niechęcią do dogmatyzmu, lecz niechęć ta nie jest istotą postawy sceptycznej. Wynika on raczej z przyjęcia do wiadomości niechcianej skądinąd niepewności poznania. Sceptyk nie usiłuje nas przekonać, że dążenie do poznania jest złe, tylko pokazać, że jest nieskuteczne. Sceptycyzm opiera się na pewnej prawdzie przygodnej, a nie koniecznej. Traktowanie jakiejkolwiek prawdy przygodnej jako normy jest wielce ryzykowne. Sceptyk

4 S. Wróbel, Lektury retroaktywne. Rodowody współczesnej myśli filozoficznej, Kraków 2014, 34. 
byłby złym doradcą (szkodliwym dogmatykiem) w świecie, w którym radykalnie poprawiłyby się ludzkie zdolności poznawcze.

2. Osłabienie zasady tożsamości podmiotu sprawia, że cudze roszczenia pozostają bez odpowiedzi, zawieszone w swoistej moralnej próżni bez odpowiedzialności; jest to świat, w którym wszyscy uczestnicy komunikacji zadają ciosy, lecz nikt nie cierpi z ich powodu. Praktycznie rzecz biorąc, jest to rozwiązanie skuteczne, lecz z moralnego punktu widzenia puste.

3. Każda próba zastąpienia języka normatywnego językiem deskryptywnym opiera się na silnych założeniach, najczęściej scjentystycznych, choć nie brakowało i spirytualistycznych wersji tej redukcji, na przykład w doktrynie o predestynacji lub w niektórych nurtach gnostycyzmu. Założenia te same zawierają silne założenia normatywne, które pozostają nieujawnione i przez to niezrozumiałe. Nie inaczej jest z psychoanalizą. Owszem, normy są trudne do zrozumienia i uzasadnienia, lecz ich nienormatywne interpretacje nie stanowią żadnego postępu - jedynie pozornie zwiększają zdolność samorozumienia i kierowania sobą.

4. Postulat swobody w używaniu rozumu wskazuje trafnie zagrożenie, że podmiot poznania staje się poniekąd zakładnikiem swojej wiedzy; nie jest w stanie efektywnie uwzględnić tego, czego nie wie, lub nie jest pewien. Prowadzi to do następującego paradoksu: (1) należy opierać się wyłącznie na tym, co wiadome, świadomie ignorując ograniczenia własnej wiedzy. (2) Ignorując ograniczenia wiedzy nie wie się, co jest wiadome, a co niewiadome, nie można więc się na tym oprzeć. Akceptacja tego paradoksu prowadzi do irracjonalności.

5. Ironia jest niezwykle ważnym narzędziem ludzkiego umysłu, lecz przyczynia się ona do lepszego ukonstytuowania podmiotu tylko wtedy, gdy przyjmuje postać autoironii. Ta ostatnia zakłada wyrafinowaną samowiedzę i nie da się sprowadzić 
do pewnej postaci dyskursu, czy też postanowienia, że zajmie się pewną postawę. Mimo podobieństwa nazwy, ironia i autoironia są odległymi od siebie uzdolnieniami człowieka. Pierwsza występuje często bez drugiej.

6. Dyskursywne przemieszczenia są pewną funkcją swobody i ironii. Trzeba jednak zaznaczyć, że dokonujemy ich pod wpływem konieczności - uciekając od aporii. Tego przymuszenia nie należy podnosić do rangi reguły. Problem wspó1czesnych krytyk podmiotowości polega na tym, że oczekują, iż będziemy wybierać w sposób nieprzymuszony to, co przez wieki wybierane było tylko z przykrej konieczności, jako wymuszone odstąpienie od ideału. Taka strategia obronna umysłu nie powinna być podnoszona do rangi pozytywnej reguły, nawet jeśli nie ma widoków na usunięcie warunków, które wymuszają ową obronną strategię. Warunki, w których toczy się ludzka komunikacja, wymagają wielu strategii dyskursywnego przetrwania, lecz uznanie ich za normalną kondycję człowieka, oznaczałoby radykalne zapomnienie o ich zasadniczej niewłaściwości.

Ten przegląd wątpliwości co do ducha współczesnej krytyki silnej, racjonalnej podmiotowości jest tu z konieczności pobieżny i sam może budzić wątpliwości. W tych rozważaniach chodzi jednak nie o cały zakres sporu, lecz o jeden tylko problem: drażliwość. Poszukuję kulturowych, dyskursywnych, a w dalszej perspektywie również pedagogicznych środków, które pozwoliłyby tę własność czy postawę utrzymać w akceptowalnych ramach. $Z$ tego punktu widzenia zarówno postulat radykalnego ograniczenia dyskursu odwołującego się do wartości, jak i strategie osłabiania roszczeń związanych z racjonalną podmiotowością nie przekonują - słuszny krytyczny rdzeń w nich zawarty służy dobrze innym celom, stanowiąc ważny głos w dyskusji filozoficznej, lecz owo zagrożenie mowy przez nią samą - tak wyraźne w fenomenie drażliwości - pozostaje jakie było. 


\section{RADYKALNY KRYTYCYZM}

Nie da się usunąć drażliwości przez krytykę pojęć normatywnych i przez rozluźnienie wymagań związanych z racjonalnością. Mój postulat jest dokładnie odwrotny: należy wzmocnić kryteria racjonalności za pomocą rygorystycznej krytyki. Tylko radykalna postawa krytyczna może zachować normatywny sens kultury, a zarazem wydobyć nas z pułapki narastającej drażliwości. Jest tak dlatego, że postulowana tu krytyka, z jednej strony, ma charakter pozytywny, zmierza do ujawnienia podstaw przekonań i postaw u wszystkich uczestników komunikacji, a tym samym sprzyja powstawaniu krytycznej wspólnoty. Krytyka ta nie zmierza do ustanawiania i maksymalizowania różnicy. $Z$ drugiej strony ma określone skutki normatywne, nie zmniejsza wymagań, lecz zwiększa je w stosunku do uczestników komunikacji.

Rola filozofii w kształtowaniu się tak pojmowanego krytycyzmu jest szczególna, ponieważ istotą filozofii jest misja krytyczna. Krytyka filozoficzna uderza w bardzo wiele własności społeczeństwa i kultury i wynikających $\mathrm{z}$ nich praktyk, lecz zawsze $\mathrm{z}$ krytycznym odniesieniem do samej siebie - do podstaw własnego krytycyzmu. Ze względu na tę cechę nie można jej sprowadzić do innych aktów i postaw krytycznych: politycznych, obywatelskich, artystycznych, religijnych. Tylko filozofia jest krytyką własnej krytyki - kiedy robią to inne dyscypliny, stają się tym samym filozofią 5 .

Dzisiaj, po fali krytycznej filozofii z początku XX i w pierwszych dziesięcioleciach po II wojnie światowej, filozofia przeżywa bezprecedensowy kryzys tej najważniejszej dla siebie misji. Skomplikowana i subtelna jak nigdy wcześniej, filozofia zdaje się dostarczać coraz słabszych impulsów krytycznych i niewiele pożywki dla rozumnego

5 Poniższe uwagi o krytycznej misji filozofii są zwięzłym podsumowaniem rozumowania zaprezentowanego w publikacji R. Piłat, Filozofia jako radykalna krytyka, w: Filozofia 2.0, red. M. Soin, Warszawa 2015, 49-74. 
kierowania samym sobą. Myślowe osiągnięcia filozofii nie powiększają krytycznego potencjału kultury, pozostając w obrębie tego, co Gaston Bachelard nazwał filozofią filozofów 6 . W tej sytuacji warto ponownie przemyśleć te koncepcje filozoficzne, które postulat krytyczności formułowały szczególnie wyraźnie. Oto trzy idee krytyczne w najbardziej syntetycznych sformułowaniach wraz z wątpliwościami co do ich zasadności i skuteczności.

Stanowisko Maxa Horkheimera: Krytyczność była, jak wiadomo, centralną ideą Szkoły Frankfurckiej. Zdaniem Horkheimera, „prawdziwa społeczna funkcja filozofii polega na krytyce stanu obecnego (...). Głównym celem krytyki jest niedopuszczenie do zagubienia się ludzi w ideach i sposobach postępowania, jakie oferuje im społeczeństwo w jego obecnej formie. (...) Ostatnie stulecie europejskich dziejów wyraźnie pokazało, że ludzie mimo całej ich pewności siebie, nie są zdolni urządzić swego życia zgodnie $\mathrm{z}$ własnymi wyobrażeniami o humanizmie. Przepaść dzieli idee, według których oceniają siebie i świat, od rzeczywistości społecznej, którą reprodukują przez swoje działania"7.

Jednak pomimo wyraźnych zastrzeżeń Horkheimera dystansujących jego podejście od socjologizmu, ten ostatni zaznacza się wyraźnie w jego koncepcji i ogranicza ją. Nie pozwala rozwinąć i nasycić treścią owego metaforycznego wyrażenia „wniesienie rozumu do świata". W marksizmie, z którego czerpie Horkheimer, autonomia rozumu i to, że może być on wnoszony do świata są ograniczone podstawowym dogmatycznym założeniem: Droga do najszerszej możliwej podstawy naszych poglądów nie może przebiegać poza interesem klasowym, lecz przeciwnie, jest ściśle związana z klasowym interesem proletariatu.

6 G. Bachelard, Filozofia, która mówi nie. Esej o filozofii nowego ducha w nauce, tłum. z franc. J. Budzyk, Gdańsk 2000, 14.

7 M. Horkheimer, Społeczna funkcja filozofii, w: tenże, Społeczna funkcja filozofii. Wybór pism, tłum. z niem. R. Rudziński, Warszawa 1987, 235, 239. 
Stanowisko Roberta Spaemanna: Filozof ten kładzie nacisk na to, że sama krytyczność musi mieć podstawę i że krytyki nie można traktować jako oczywistej nawet wtedy, gdy sprzeciwia się ewidentnemu złu. $Z$ drugiej strony, krytyka nie może być kierowana wyłącznie dążeniem emancypacyjnym. Proponując zmiany w jakiejkolwiek dziedzinie: nauce, sztuce, instytucjach, trzeba być gotowym do wykazania normatywnej podstawy swojej propozycji. Wykazując hipotetyczność naszych przekonań, odwołujemy się w końcu do czegoś, co niehipotetyczne ${ }^{8}$. Jeśli dobrze rozumiem Spaemanna, owe normatywne podstawy samej krytyczności sprowadzają się do pytania o podmiot: Kim stanie się człowiek poddany owym zmianom? Nie cechy zdarzeń i przedmiotów są podłożem norm, lecz miejsce w świecie samego podmiotu - udane zmaganie się ze sprzecznościami, jakie to miejsce wytwarza i ujawnia.

Stanowisko to budzi jednak wątpliwości. Spaemann rozumuje następująco: Najpierw musi wystąpić uzasadnione pragnienie racjonalnego myślenia i analogicznie sprawiedliwości, potem dopiero krytyczny dyskurs społeczny. Owo pragnienie racjonalności przypomina w swej intencji wnoszenie rozumu do świata u Horkheimera. W obu przypadkach metaforycznie odsyła się do enigmatycznego podmiotu, który zajmuje uprzywilejowaną, ekscentryczną pozycję w rzeczywistości i ma do niej dostęp niejako od zewnątrz. Jednak działania tego podmiotu, a nawet sama ekspresja pragnień, w tym również pragnienia racjonalnego życia, dokonywane są wewnątrz praktyk społecznych. Racjonalny podmiot jest więc skazany na udawanie własnej transcendencji, czy, mówiąc ostrzej, na nieakceptowalną hipokryzję.

Stanowisko Jürgena Habermasa: Niemiecki filozof zdaje sobie sprawę z paradoksu, zgodnie z którym dobra, uzasadniona krytyka musi czynić wiele założeń rzeczowych, dla których poświęca

8 R. Spaemann, Przekonania w cywilizacji hipotetycznej, w: tenże, Kroki poza siebie. Przemówienia i eseje, tłum. z niem. J. Merecki, Warszawa 2012, 34-40. 
w znacznej mierze (a czasem całkowicie) swój krytycyzm. Nie tylko filozofia, lecz cała kultura cierpi na chorobę niekrytycznego krytycyzmu. Paradoksalnie, głos krytyczny pochodzi dziś głównie od dogmatyków, czy wręcz fundamentalistów, im bowiem najłatwiej sformułować zarzuty - dysponują uniwersalnym językiem oskarżenia. W innym położeniu jest krytyk filozoficzny - radykalny nie w ostrości swych sądów, jak fundamentalista, lecz co do głębi samego krytycyzmu. Głębia ta pochodzi z wysiłku odwracania wektora krytyki, odnoszenia jej do samego krytycznego podmiotu. Krytyczna postawa jest tu stale weryfikowana, przez ocenę wkładu danego aktu krytycznego w ujawnienie ostatecznych normatywnych podstaw ludzkiej podmiotowości. Habermas formułuje koncepcję, która wychodzi naprzeciw potrzebie ufundowania takiego krytycznego i samokrytycznego podmiotu. Podstawą jego poglądu jest komunikacja. Cokolwiek mamy do powiedzenia na temat samego siebie, świata, a nawet samej komunikacji, musi być najpierw ustanowione jako akt komunikacji. Nasze sądy niosą wiążącą treść, jeśli są skierowane do innych rozumnych podmiotów i są rozumiane przez te podmioty, a także stają się przesłanką ich własnych wypowiedzi. $\mathrm{Z}$ tego punktu widzenia Habermas formułuje kilka konkretnych i ważnych tez krytycznych: (1) o tym, że świat życia został skolonizowany przez ekonomię i biurokrację; (2) o tym, że sens wyrażany $\mathrm{w}$ języku jest coraz bardziej poddany instrumentalizacji - bardziej związany jest ze społecznymi funkcjami mowy, niż z tym, do czego mowa się odnosi; (3) o tym, że „zniekształcona komunikacja przybiera postać oderwania znaczenia od prawomocności, mówienia od działania, znaczenia od intencji9. Pozytywną ideą Habermasa jest racjonalizacja świata życia w miejsce jego kolonizacji ${ }^{10}$. Podstawowym instrumentem tej racjonalizacji jest dbanie o jakość

9 A. Dupeyrix, Zrozumieć Habermasa, tłum. z franc. M. N. Wróblewska, Warszawa 2013, 198.

10 Tamże, 197. 
komunikacji - poprawianie jej zniekształceń. Wysiłek krytyczny filozofii ma być zatem skierowany na komunikację ${ }^{11}$, a poprzez nią na inne dziedziny życia: postawy moralne, wybory polityczne, rozwiązania instytucjonalne.

Propozycja Habermasa ma jednak poważne ograniczenia: (1) Alex Honneth zarzucił jej, że koncentrując się na komunikacji, czyli mowie, Habermas pozostaje ślepy na te cierpienie i niesprawiedliwości, które nie wyrażają się w mowie ${ }^{12}$; (2) Silne są racjonalistyczne założenia Habermasa, co sprawia, że poza zasięgiem analizy pozostaje niego język poetycki, wbrew oczywistej intuicji, że właśnie on był niejednokrotnie nośnikiem najgłębszej krytyki; (3) Metoda Habermasa wymaga odwołania się do idealnego modelu komunikacji jest on nie tylko nierealistyczny z definicji, lecz prowadzi do aporii, ponieważ musi być przedmiotem pragnienia (tylko wtedy może być podstawą krytyki), a pragnienie to musiałoby być równoznaczne z pragnieniem swoistego końca historii; (4) Strategia krytyczna Habermasa zdradza, zdaniem Judith Butler ${ }^{13}$, ukryty autorytaryzm, ponieważ krytyk stoi tu całkowicie poza krytykowanymi stosunkami i zjawiskami - w stosunku do siebie bezkrytyczny.

Przedstawiłem trzy wybrane poglądy na krytyczną funkcję filozofii. Ich wspólną wadą jest to, że mylą samą myśl krytyczną z jej zastosowaniami. Można się zgodzić na to, że krytyka ma doprowadzić do uporządkowania i poprawiania idei (Horkheimer), lecz to nie znaczy, że krytyka jest analizą idei. Można się zgodzić, że krytyka zmierza do umocnienia rozumności i sprawiedliwości i że musi być sama uzasadniona (Spaemann), lecz to nie znaczy, że krytyka jest doskonaleniem uzasadnienia. Można się wreszcie zgodzić, że doskonalenie komunikacji jest kluczem do wielu pozytywnych zmian społecznych

11 J. Habermas, Zur Architektonik der Discursdifferenzierung, w: tenże, Zwischen Naturalismus und Religion. Philosophische Aufsatze, Frankfurt am Main 2005, 89.

12 Ten zarzut przytaczam za A. Dupeyrix, dz. cyt., 132-138.

13 J. Butler, What is Critique? An Essay on Foucault's Virtue, Transversal 5(2001), http:// eipcp.net/transversal/0806/butler/en [dostęp: 27.10.2017]. 
i moralnych (Habermas), lecz nie znaczy to, że krytycyzm sprowadza się do doskonalenia komunikacji. Postawa krytyczna dotyczy, moim zdaniem, przede wszystkim relacji do samego siebie, a nie relacji do świata, w którym dostrzega się negatywne zjawiska. Nie można mylić krytycyzmu z protestem przeciw złu - po to, by opierać się niesprawiedliwości, irracjonalności, hipokryzji itd. nie trzeba być krytycznym $\mathrm{w}$ prezentowanym tu radykalnym sensie - wystarczy być inteligentnym i wrażliwym. Krytyk w sensie potocznym jest bardzo często skrajnie niekrytyczny, o czym nie trzeba przekonywać dziś, po stuleciu wypełnionym doktrynami słusznymi w głoszonym sprzeciwie, a przy tym ideologicznymi i skrajnie bezrozumnymi w ich pozytywnej treści. Również dzisiejsze ruchy protestu i emancypacji, od transhumanizmu do religijnego fundamentalizmu, kierują się często na słuszne zewnętrzne cele - dostrzegając trafnie zjawiska negatywne, lecz same pozostają całkowicie bezkrytyczne. Potrafią uzasadniać swoje stanowiska przez odwołanie się do zła w świecie, lecz nie widzą, że ich konstatacje zakorzenione są w normatywnym podłożu, które trzeba ujawnić i przemyśleć. Najczęściej jest bowiem tak, że krytyk i krytykowany podzielają większość założeń dotyczących sprawiedliwego świata, lecz mimo to powstaje rozbieżność, której źródło pozostaje nieznane i jest najczęściej zastępowane mitologicznym obrazem przeciwnika.

Prawdziwą krytyką jest ujawnianie źródła własnej postawy w radykalnej refleksji. Krytyczna osoba zmierza do ujawnienia tej części własnego obrazu świata, która jest dla niej najgłębszym zrozumiałym źródłem zobowiązania. Jednak ujawnienie źródła nie wystarczy trzeba jeszcze zapytać, czy realizacja tego zobowiązania czyni tę osobę lepszą. Oczywiście również mówienie o samodoskonaleniu zawiera założenia normatywne i zawsze zachodzi niebezpieczeństwo, że ten sam system idei, który definiuje to, do czego dążymy, definiuje również samego dążącego - stajemy się wówczas nieodróżnialni od swoich przekonań i wartości, popadając we wszystkie wspomniane wcześniej aporie. Krytycyzm jest właśnie obroną przed tego rodzaju 
aporiami, a to za sprawą rozumienia i ujawniania rozdźwięku pomiędzy perfekcjonistycznym ideałem samego siebie i środkami, którymi się dysponuje, by ten ideał realizować. Nie stajemy się lepsi realizując swoje pragnienia i przekonania, lecz poddając je krytyce. Wykrywanie i rozumienie tej rozbieżności nazywam właśnie radykalną krytyką. Podkreślę raz jeszcze jak bardzo pojęcie to różni się od potocznego pojęcia krytyki: nie chodzi o to, by nie zgadzać się z czymś na mocy swoich przekonań, wartości czy interesów, lecz o to, by poddawać testowi te przekonania, wartości i interesy - podstawy wyrażonej niezgody. W tym sensie przedmiotem krytyki nie są te przekonania, z którymi się nie zgadzamy, czy wartości, których nie uznajemy, lecz właśnie - a może przede wszystkim - te przekonania i wartości, które żywimy i uznajemy. $Z$ punktu widzenia radykalnej krytyki różnica pomiędzy zgodą i niezgodą, skłanianiem się do czegoś i oporem, nie ma wielkiego znaczenia.

Radykalna krytyka ma na celu coś innego niż własną słuszność. Bliższa jest raczej ideałowi kierowania samym sobą. W tym ostatnim nie chodzi o potocznie rozumiane porządkowanie i dyscyplinowanie własnego działania, lecz o kierowanie perfekcjonistyczną dynamiką własnej osoby za pomocą przemyślanego wykorzystania własnych zasobów. Ten sens krytyki został wyrażony w Kantowskiej idei oświecenia. Oznacza ona osiągnięcie zdolności do kierowania samym sobą, którą to zdolność Kant nazwał dojrzałością.

Według Kanta rozum musi stanąć przed własnym trybunałem, aby mógł uzasadnić swoje roszczenia. Powstaje jednak pytanie, czym jest trybunał? Nie da się go określić wyłącznie negatywnie jako odrzucenie tego, czego się nie akceptuje. Po odrzuceniu zawsze wyłania się jakaś treść pozytywna, którą trzeba rozumieć; ponadto, samo odrzucenie jest aktem o pewnej pozytywnej treści. Obie te treści z łatwością uchodzą uwadze krytycznego umysłu. Ciekawie pokazuje to Philip Quadrio w studium o idei krytyki u Rousseau i Kanta. Jak wiadomo, Jacques Rousseau poddał krytyce naukowy rozum, zarzucając naukom, i sztukom to, że jedynie zaciemniają ludzkie 
zniewolenie, nie uwalniając od niego ${ }^{14}$. Lecz w jego idei emancypacji tkwi rozróżnienie na wolność przyrodzoną i wolność, którą trzeba zdobyć15. Wprawdzie człowiek stał się bezdomny, wygnany z natury przez racjonalizm, lecz tylko rozum może mu pomóc powrócić na swoje miejsce ${ }^{16}$. W bardziej dosadny sposób ujął to Kant, dla którego krytyka inna niż ściśle racjonalna byłaby dążeniem do emancypacji bez poczucia słuszności.

Powstaje jednak pytanie: Czy sama radykalna krytyka - ów trybunał rozumu - ma własną podstawę? Wydaje się, że Kant widział ją $\mathrm{w}$ transcendentalnej analizie - w ujawnieniu tego, co nazywał transcendentalnym złudzeniem ${ }^{17}$. To ostatnie polega na niedostrzeganiu, że zadaje się pytania, na które nie ma odpowiedzi. Emancypacja (nowo zdobyta wolność) oznacza dla Kanta niepodleganie złudzeniu, które skazuje człowieka na łaskę losu, podsuwając mu nierealistyczne cele. Jednak wielu współczesnych filozofów nie przyjęłoby takiej wersji krytycznego rozumu. Zdaniem Michela Foucaulta są dwie wersje Kantowskiej krytyki: pierwsza zawarta w Krytyce czystego rozumu, druga w rozprawce Czym jest Oświecenie. W pierwszej szuka Kant transcendentalnej podstawy krytyki, w drugiej polega raczej na pewnym etosie, mianowicie na wysiłku emancypacji. Quadrio ma wprawdzie wątpliwości, czy jest to dobra interpretacja, ponieważ u Kanta projekt transcendentalnego ugruntowania i projekt emancypacyjny są ściśle powiązane, tu jednak możemy zostawić spór historyczny na boku. Istotne jest zastanowienie się nad tym, jak silne warunki musi spełnić ów etos emancypacji, by rzeczywiście był emancypacją, a nie jej złudzeniem. W tym punkcie właśnie widzę pożytek z mojej tezy o radykalnej krytyce: emancypacja uzyskuje

14 Ph. A. Quadrio, Rousseau, Kant and Philosophical Auto-Criticism: The Practical ends of Critical Thinking, w: Conceptions of Critique in Modern and Contemporary Philosophy, red. K. de Boer, R. Sinderegger, London 2012, 51.

15 Tamże, 54.

16 Tamże, 58.

17 Tamże, 62. 
uzasadnienie przez odniesienie do doskonalenia człowieka mocą radykalnej refleksji, a nie odwrotnie. Doskonalenie nie zachodzi wtedy, gdy zachodzi emancypacja, lecz odwrotnie: z emancypacją mamy do czynienia tylko wtedy, gdy spełnia warunek doskonalenia.

Przedstawiona powyżej idea radykalnej krytyki wydaje mi się wystarczającą odpowiedzią na problem drażliwości. Aporia drażliwości polega na tym, że większa subtelność (swoista gęstość) kultury i większy zakres praw osobistych prowadzą do destrukcyjnej dla komunikacji drażliwości - systemy przekonań i wartości są powiązane i związki te są znane ich posiadaczom; wiedzą oni, że różnice zapatrywań sięgają głęboko, do samej podstawy tożsamości - podejrzewają, że sięgają zbyt głęboko, by dało się znaleźć dla nich dyskursywne rozwiązanie. Radykalna krytyka poddaje pod wątpliwość ową budząca nieufność głębię. Zarazem ujawnia znacznie większy stopień zgody pomiędzy opozycyjnymi przekonaniami i wartościami niż są w stanie przyznać drażliwi uczestnicy komunikacji. Wszystko to nie znaczy, że mamy do dyspozycji zestaw krytycznych narzędzi filozoficznych, które czekają tylko na użycie. Jak już wspomniałem, krytyka filozoficzna w swoim pragnieniu źródłowości i radykalizmie, musi przede wszystkim krytykować sama siebie. Wielu dzisiejszych filozofów nazywa siebie krytycznymi, lecz tę autokwalifikację trzeba każdorazowo sprawdzać. Krytykowanie nie jest jeszcze filozoficznym krytycyzmem i wiele współczesnych poglądów jest krytycznych jedynie $\mathrm{w}$ potocznym, nie $\mathrm{w}$ filozoficznym sensie tego słowa.

\section{KRYTYCYZM W SZKOLE}

Po zarysowaniu wizji radykalnej krytyki jako remedium na komunikację przenikniętą nieufnością i drażliwością, chcę się zastanowić nad praktycznymi konsekwencjami tej idei w dziedzinie edukacji. Jeśli radykalna krytyka nie ma pozostać jedynie teoretyczną możliwością, trzeba wskazać zakres i narzędzia jej zastosowania. Tym zakresem jest kształcenie, a proponowanym narzędziem jest 
dociekanie filozoficzne rozumiane jako integralna część procesu edukacyjnego. Idea dociekań filozoficznych w szkole jest dziś dość znana. Miała ona więcej niż jedno źródło, lecz w tym miejscu chcę nawiązać do konkretnego programu przedstawionego prawie pół wieku temu przez zmarłego w 2010 roku amerykańskiego filozofa Matthew Lipmana. Pomysł pojawił się pod nazwą Pbilosophy for Children, lecz rozwijanie go w polskim środowisku nadało mu swobodniejsze ramy i odrębną metodologię. Istota pozostaje ta sama: uruchomienie procesu krytycznego myślenia, które ma zarazem sens kooperatywny. Nie prowadzi do antagonizacji, lecz do ujawnienia zasobów poznawczych uczestników dialogu, co z kolei wzmacnia środki rozwiązywania problemów, a w konsekwencji poczucie wspólnoty. Twórca programu używał w tym kontekście określenia „wspólnota dociekająca" (community of inquiry). Wieloletnie doświadczenia w realizacji programu w Polsce prowadzą do wniosku, że wspólnota tego rodzaju jest osiągalna, a krytycyzm jest jej najważniejszym komponentem. Pierwotna Lipmanowska metoda prowadzenia zajęć jest dość restrykcyjna: polega na gromadzeniu pytań i prowadzeniu dyskusji za pomocą wypowiedzi zaczynających się od sformułowań „Zgadzam się, ponieważ...”, „Nie zgadzam się, ponieważ...”. Jej zaletą jest konieczność argumentowania również w przypadku zgody, nie tylko niezgody, dokładnie tak, jak postulowałem to formułując powyżej filozoficzny ideał radykalnej krytyki.

Kształcenie krytycyzmu jest obszernym zadaniem, co widać w poniższej liście norm, które w ciągu wyłoniły się z praktyki szkolnej i wskazują konkretne umiejętności, potrzebne do powstania postawy krytycznej. Naczelna zasada krytycznej dyskusji głosi, że stopień uznania przekonania nie może być wyższy niż stopień jego uzasadnienia. Aby móc przestrzegać tej zasady, trzeba opanować następujące umiejętności ${ }^{18}$ :

18 Wymieniam, streszczając za: Model Minimum Kompetencji Myślowych, publikacja zbiorowa przygotowana przez zespół Stowarzyszenia Edukacji Filozoficznej PHRONESIS w ramach 
1. Umieć ocenić własny stopień przekonania. Zakłada to między innymi: (1) zdolność wyobrażenia sobie, do jakich działań zobowiązuje nas posiadane przekonanie i czy jesteśmy do tych działań zdolni; (2) zdolność wyobrażenia sobie, jakie inne (alternatywne) przekonania można by w danej sytuacji posiadać; (3) zdolność oceny, jak wiele innych przekonań jest połączonych logicznie $z$ danym przekonaniem.

2. Rozumieć nieabsolutność i zasadniczą zmienność własnych przekonań.

3. Nie wiązać własnej godności z prawdziwością własnych przekonań; akceptować niedoskonałość i otwartość na nowe przekonania. Wprawdzie zrozumiałe jest przywiązanie do własnych zapatrywań - stanowią one często ważną część tożsamości danej osoby, lecz najlepszą drogą do utrzymania tej relacji jest doskonalenie własnych przekonań, a nie trzymanie się ich.

4. Umieć obmyślać alternatywy dla własnych poglądów. Gotowość do przyjęcia odmiennych przekonań na próbę i ich sprawdzanie stanowią podstawowy instrument rozwoju wiedzy.

5. Umieć identyfikować przekonania irracjonalne, zabobonne, oparte na uprzedzeniach i opierać się irracjonalnym impulsom.

6. Umieć łączyć kompetencje logiczno-semantyczne ze zdolnością do porozumiewania się.

7. Dostrzegać to, że cudzy odmienny pogląd, kłopotliwy kontrargument lub dociekliwe, krytyczne pytania ostatecznie przynoszą korzyść wszystkim zaangażowanym w komunikację.

8. Mieć świadomość własnej niewiedzy. Nie wystarczy ogólne poczucie, że wiedza ludzka jest niedoskonała - to przyznaje

projektu PO KL 09.02-30-365/10 Pozwolić uczniom myśleć, współfinansowanego przez Unię Europejską w ramach Europejskiego Funduszu Społecznego. 
prawie każdy. Potrzebne jest dostrzeżenie wtasnej niewiedzy tu i teraz, wskazanie dokładnie obszaru, którego dotyczy i twórcze szukanie dróg jej usunięcia.

W środowisku szkolnym krytycyzm budzi obawy, ponieważ słowo „krytyka” rozumiane jest na ogół w potocznym sensie niezgody, sprzeciwiania się, sporu. Pojęcie krytyki, którego broniłem w tym artykule, ma sens pozytywny. Ponadto ma sens zarówno w sytuacji zgody, jak i niezgody, w istocie sprowadza się do pewnych pozytywnych i cennych umiejętności myślowych i komunikacyjnych oraz do woli ich stosowania. Tego rodzaju krytycyzm przychodzi zupełnie naturalnie wraz z nabywaniem języka i umiejętności komunikowania się, dlatego jeśli chodzi o jego doskonalenie, nie ma praktycznie granic wiekowych - krytyczne dociekania można prowadzić równie dobrze z dziećmi z pierwszych klas szkoły podstawowej, jak z licealistami. Dominacja wiedzy encyklopedycznej w szkole sprawia, że umiejętności krytyczne postrzega się jako przeszkodę, kojarzą się bowiem $\mathrm{z}$ chaosem myślowym i zaprzepaszczaniem wysiłku włożonego w nabycie wiedzy. Tymczasem krytyczne myślenie nie zajmuje się podważaniem wysiłków poznawczych, a tym mniej tworzeniem chaosu, lecz ujawnia racjonalną podstawę naszych przekonań wartości i postaw. Moje własne doświadczenie edukacyjne pokazuje, że tak rozumiany krytycyzm rzeczywiście łagodzi obyczaje, powściągając drażliwość i otwierając drogę do poważnego i wyzbytego lęku uwzględnienia w praktyce szkolnej tematów wrażliwych światopoglądowo. Kiedy krytycyzmu brak, powstaje błędne koło: drażliwość prowadzi do unikania pewnego typu dyskusji, zaś unikanie prowadzi do niewiedzy i podejrzeń, które jeszcze bardziej wzmagają drażliwość.

\section{BIBLIOGRAFIA}

Ariely D., Loewenstein G., Prelec D., Tom Sewyer and the Construction of Value, w: The Construction of Preference, red. P. Slovic, S. Liechtenstein, Cambridge 2006. 
Bachelard G., Filozofia, która mówi nie. Esej o filozofii nowego duch a w nauce, thum. z franc. J. Budzyk, Gdańsk 2000.

Butler J., What is Critique? An Essay on Foucault's Virtue, Transversal 5(2001), http:// eipcp.net/transversal/0806/butler/en.

Dupeyrix A., Zrozumieć Habermasa, tłum. z franc. M.N. Wróblewska, Warszawa 2013.

Habermas J., Zur Architektonik der Discursdifferenzierung, w: tenże, Zwischen Naturalismus und Religion. Philosophische Aufsatze, Frankfurt am Main 2005.

Horkheimer M., Spoteczna funkcja filozofii, w: tenże, Spoteczna funkcja filozofii. Wybór pism, tłum. z niem. R. Rudziński, Warszawa 1987.

Piłat R., Filozofia jako radykalna krytyka, w: Filozofia 2.0, red. M. Soin, Warszawa 2015.

Quadrio Ph., Rousseau, Kant and Philosophical Auto-Criticism: The Practical ends of Critical Thinking, w: Conceptions of Critique in Modern and Contemporary Philosophy, red. K. de Boer, R. Sinderegger, London 2012.

Spaemann R., Przekonania w cywilizacji hipotetycznej, w: tenże, Kroki poza siebie. Przemówienia i eseje, tłum. z niem. J. Merecki, Warszawa 2012.

Straub E., Von Tyrraney der Werte, Klett-Cotta, Stuttgart 2010.

Tannen D., Cywilizacja któtni. Jak powstrzymać amerykańskq wojnę na stowa, Poznań 2003.

Wróbel S., Lektury retroaktywne. Rodowody wspótczesnej myśli filozoficznej, Kraków 2014.

\section{TOUCHINESS AND CRITICISM.}

\section{ON THE ROLE OF PHILOSOPHICAL CRITICISM IN CULTURE AND EDUCATION}

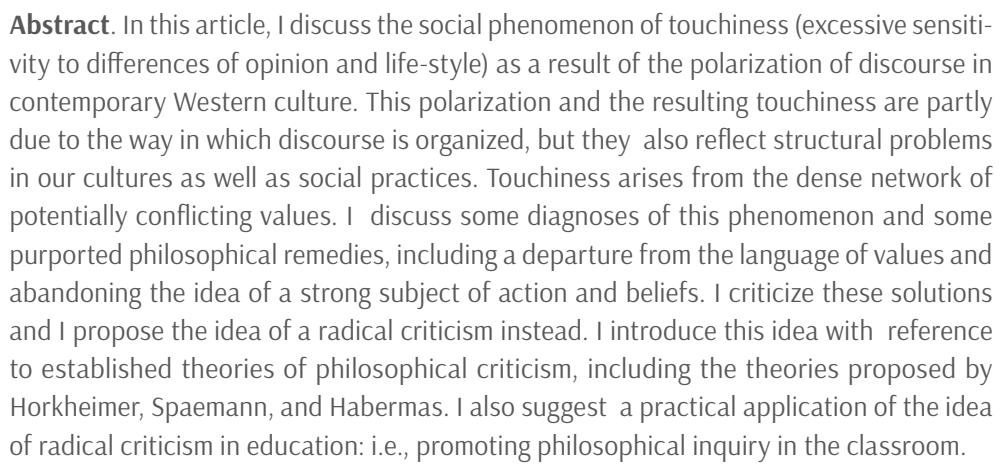


Key words: criticism, values, modern subject, irony, touchiness, education

\section{Robert PIŁAT}

r.pilat@uksw.edu.pl

Uniwersytet Kardynała Stefana Wyszyńskiego w Warszawie, Instytut Filozofii

Wóycickiego 1/3, 01-938 Warszawa

DOI: 10.21697/spch.2018.54.2.01 